hippocampal commissure and the anterior commissure. These results support the conclusions of Owen, and are opposed to those of Flower.

(8) Prof. J. Playfair McMurrich, the Early Development of the Isopods. The author described the structure and mode of segmentation of the typical centrolecithal ovum of the Isopod Jara, calling attention to the early differentiation of the germ layers, which may be traced back to the eight-celled stage. The mesoderm forms at first a band of cells surrounding the embryo, and later concentrates towards the ventral surface to form the blastodisc, behind which is the endoderm, these two layers be. coming later enclosed by the ectoderm, which grows back over them by teloblastic proliferation.

(9) Dr. J. Beard gave some notes on Lampreys and Hag. fishes.

(I0) Prof. G. B. Howes and Mr. J. Harrison, on the Skeleton and Teeth of the Australian Dugong. The authors described the process of vertebral-epiphysis formation, showing that epiphyses, so far as represented, are formed late, and are rapidly merged into the substance of the vertebral body. They described the formation of structures which might, perhaps, be regarded as anticipatory of supernumerary phalanges, and pointed out that their observations lent no support to Kukenthal's view of the epiphysial nature of such phalanges. Five mandibular teeth were found to be present in the anterior region of each ramus in the manatee, and one of these they claimed as a canine. They recorded the discovery of milk predecessors to the first upper and the four lower incisors (?) of the dugong, and of the two anterior mandibular cheek. teeth of the manatee; and discussed the bearings of these facts on the inter-relationships and affinities of the order Sirenia.

(I I) Dr. H. C. McCook-Can Spiders Prognosticate Weather Changes? Dr. McCook first stated briefly the widespread popular opinion that spiders fairly indicate the weather by ceasing to spin before foul weather, and weaving freely before fine weather. He then gave a few extracts from his journal of observations on this point extending over six years, the tenor of which is that the popular opinion has no basis in fact. Many species of orb-weavers, which were colonized and kept under close observation, made snares freely before rains and storms, frequently even in the intervals between heavy rains.

(12) Mr. G. Swainson, some Notes on Marine and Freshwater Chironomus.

(13) Rev. Hilderic Friend, on British Earthworms. The author distinguishes between the four genera-Lumbricus, Allolobophora. Allurus, and Dendrobana - to which British earthworms belong, and gives an account of the different species, some of which are new to science.

(I4) Mr. H. Newman Laurence, the Human Body as a Conductor of Electricity.

(15) Prof. J. B. Haycraft, Fertilization of the Eggs of the Stickleback.

The two following papers, also on the programme, were taken as read :- -

(16) Prof. Emile Yung, la Fonction Dermatoptique chez le Ver de Terre, and

(I7) M. J. Richard, Note sur l'CEil Latéral des Copepodes du genre Pleuromma. The lateral eye in Pleuromma is variable in position, but is more often on the right side than on the left, and seems more constant in males than in females.

The following demonstrations were also given during the afternoon:-The Formation of Pearls (by Mr. Albert F. Calvert), Interesting British Food Fishes (by Mr. E. W. L. Holt), and the Structure of Myeloxylon (by Mr. A. C. Seward)

\section{GEOGRAPHY AT THE BRITISH} ASSOCIATION.

$\mathrm{THE}$ work of the Geographical Section was overtaken in four meetings, the large attendance at which was evidence that the papers read met at least with popular approval. It is more satisfactory to gather from the opinions expressed by specialists that many of the papers were solid and original, and that from the scientific standpoint the average work was of high excellence. Without doubt the most important of the new results announced to the Section was Dr. Schlichter's admirable development of a photographic process for determining longitude by the almost disused method of lunar distances. The practical value of the invention is very great, especially with regard to the mapping of partially known continents.
Like all other departments of the Association, Section E owed much of its success to the distinguished foreigners who took part in its proceedings. The papers by the Prince of Monaco and the occasional remarks of Baron von Richthofen were much appreciated. Two ladies read papers, Mrs. Bishop recounting her adventures on the borders of Tibet with her well-known literary grace, and Mrs. Grove giving a short, bright account of the rainless regions of Chile.

Prof. James Geikie's presidential address, although based entirely on geological reasoning, was truly geographical in so far as it utilized geology only for the purpose of explaining the origin of the existing surface conditions of the globe. As presenting the only sound basis of physical geography, this opening address proved to be one of the best and most original with which Section $\mathrm{E}$ has ever been favoured. Unfortunately, Prof. Geikie was prevented by illness from presiding at all the meetings, but his place was taken by the vice-presidents, Colonel Godwin Austen, Mr. H. J. Mackinder, Mr. E. G. Ravenstein, and Mr. Coutts Trotter.

The First Ascent of Oraefa Fökull. - In the absence of the author, Mr. J. Coles read an account by Mr. F. W. W. Howell of the first ascent of Oraefa Jolsull in Iceland. Mr. Howell succeeded in making the ascent on August 12 last year, after several previous failures. Although only 6550 feet in height the mountain presented remarkable difficulties on account of the irregularity of the ice.

Place Names.-Dr. J. Burgess, in the course of a paper on place names, urged a uniform system of transliteration from Oriental alphabets as more scholarly and more satisfactory than any attempt to represent the sound of names phonetically. In no other way could uniformity of spelling be arrived at, and the diverse spellings now in use made the study of Asiatic geography in particular very toilsome and irritating. With regard to Gaelic names there were several serious errors in spelling on the ordnance map, but at the suggestion of Sir Charles Wilson a Committee of the Royal Scottish Geographical Society had taken the matter up, and aided by local committees were introducing important corrections. A lively discussion followed the reading of this paper, in which Sir Charles Wilson, Mr. Mackinder, Prof. Thomas Smith, and others took part. A Committee of the Association was formed to co-operate with the Scottish Society, and received a small grant to aid in the thorough revision of the orthography of Gaelic place names.

Effects of Rainfall in Formosa.-Mr. John Thomson, of London, gave an account of the effect of rainfall on the scenery of Formosa, illustrated by a number of fine photographs. The situation of the island and its mountainous structure conspire to give prominence to the effect of rain-action ; the wind blowing in from the warm current of the Kuro Sizwo strikes against a mountainous ridge which runs the whole length of the island and cul. minates in a summit 12,000 feet high. The mountain side to windward is scored with deep ravines, and the streams cholied with huge boulders in course of transport to the coast-plains, which are deeply covered by fine alluvium washed down from the heights.

The Windings of Rivers.-Mr. J. Y. Buchanan, in a short paper, discussed the windings of rivers from the standpoint of hydrodynamics.

Lesser Tibet.-Mrs. Bishop (Miss Isabella Bird) described a journey undertaken in 1889 , on the borderland of Tibet, which she approached from Leh, in Kashmir. The intensity of radiation at great altitudes, giving very hot days and cold nights, was observed to lead to a very rapid disintegration of the rocks, resulting in the formation of immense fields of gravel. Although presenting a vivid picture of the topography and scenery of the trans-Himalayan borderland, Mrs. Bishop entered more fully into the characteristics of the people, contrasting the false, suspicious, and cringing natives of Kashmir with the truthful, trustful, and independent people of Tibet, who always welcomed her warmly and dealt with her fairly.

The North Atiantic. - The Prince of Monaco read two papers on his oceanographical work, the first bearing on his experiments with floats on the surface circulation of the Gulf Stream, and its associated system of currents. About Io per cent. of the floats thrown over from the Prince's yacht have been recovered, and by taking into account the position in which they were found and the date, important confirmation of the theoretical system of circulation was obtained. The current was found to be a circular whirl, with its centre a short distance soulh-west of the Azores. Floats thrown over near the centre were not re-

No. I I 9 I, VOL. 46] 
covered for many years, but those launched to the north or the south were thrown ashore more speedily on the coast of France, Spain, Portugal, North Africa, or in the West Indies. The only escape from the whirl was the Gulf-Stream drift towards Norway and the Arctic Sea. The mean rate of circulation was calculated as about $4 \frac{1}{2}$ miles per day, and the rate of movement was found to be more rapid in the western than in the eastern half of the whirl. The Prince's second paper set forth the advantages which would accrue to meteorology and to navigation if the atmospheric conditions of the North Atlantic conld be observed and telegraphed daily to Europe. He pointed out that the Bermudas, the Azores, Madeira, the Canaries, and the Cape Verd Islands were, or would very soon be, in telegraphic communica. tion with Europe. If high and low level observatories were established in these islands it would be possible to construct very fair synoptic charts of the North Atlantic, and vastly improve upon the useful Pilot Charts now compiled by the Washington Weather Bureau. The Prince was willing that all observations should be collected at Monacn, where the Government of the Principality would discuss and publish the data, and he suggested that the Governments most interested should send delegates to a conference to be held next winter at Monaco in order to discuss the feasibility of the scheme. Dr. A. Buchan, in commending the Prince's suggestions, said that the surface temperature of the North Atlantic had been proved to have an influence on the direction of cyclones crossing it, and consequently on the weather of the British Islands and western Europe. He thought a properly equipped low-level station on the Bermudas was the first desideratum; then a similar station on the Azores, to be followed by a high-level observatory. The resuits at Ben Nevis warranted the expectation of great ad. vances, not only in knowing the weather of the Atlantic, but in forecasting weather for Western Europe, if the Prince's scheme received the encouragement which it deserved.

Detailed Oceanography and Meteorology. - Mr. J. Y. Buchanan described his observations on the temperature and density of the water in the Gulf of Guinea in connection with the counterequatorial current. Dr. H. R. Mill gave a brief account of the physical geography of the Firth of Forth, dwelling particularly on the relation between tidal and solar variations of temperature in the water. The puzzling fact that in the Firth of Forth the water at high tide is saltest when that phase occurs in the afternoon was explained by the high water of spring tides occurring at that hour. Mr. H. N. Dickson, in a short paper, urged the claims of meteorology as a subject of instruction with special regard to its place in physical geography.

The Desert of Atacama.-Mrs. Lilly Grove, of Oxford, gave a vivid description of a journey through the Atacama desert, including a trip by rail from Antofagasta to Uyuni at an elevation of 13,000 feet in the Andes.

Photography and Surveying.-Colonel Tanner explained the sysiem of photographic surveying which he has developed on the Himalayan survey. By the use of a finely ruled grating the angular intervals between prominent objects could be estimated, and in cases where detailed triangulation was impracticable very fair maps could be compiled from photographs taken from several prominent centres.

Determination of Longitude by Photography.-Dr. H. Schlichter communicated a most important paper, summing up a long series of experiments, and an investigation of the mathematical formulæ required in calculating longitude from lunar distances. His method enables him in favourable circum. stances to fix the longitude to within $6^{\prime \prime}$, an approximation hitherto only possible by telegraphic time comparisons. His summary is as follows :-

"Lunar distances as a means for the strictly accurate determination of geographical longitudes have been little used of late, partly on account of the splendid chronometers with which ships are now provided, and partly owing to the inaccuracies of the instruments commonly employed for lunars. For exploring expeditions on land, however, chronometers are of little value, and the other astronomical phenomena which may be used besides lunar distances are either too difficult for accurate obser. vation by the majority of travellers, or occur too seldom, or are not accurate enough. The author therefore introduces a new method of observation and measurement of lunar distances, viz. by obtaining a parallel series of photographs of the moon and a fixed star or planet on one plate, and afterwards measuring the distances on the plate. For the elimination of all possible inaccuracies of the photographic film or of the lens, the lunar distances thus registered are checked by repeatedly photograph ing on the same plate two fixed stars, the positions of which are given in the Nautical Almanac, and the angular distances of which can easily be computed therefrom. The angular dis. tances of the photographic lunars are then found by a simple proportion. The time for taking a set of eight photographic lunars on one plate does not exceed three or four minutes, and micrometric measurements show with perfect accuracy the change of the lunar distances (owing to the movement of the moon) during each interval of the eight observations. The minute accuracy of the method is hereby established. The micrometric measurements on the plate are made by means of the same réseau which is employed by the principal observatories for stellar photography, and the measurements may therefore be regarded as absolutely correct. Results thus obtained give the correct longitude of the place of observation. The author proposes to use this method for scientific expeditions into the interior of continents, \&c., as well as for the further determination and correction of secondary meridians in navigation. For both purposes it is especially adapted on account of its minute accuracy and great simplicity."

African Travels. - The whole of one day was devoted to the reading of papers bearing on Africa, almost all having reference to South Africa. Mr. E. Wilkinson described two journeys which he had made in the Kalahari Desert. Mr. Theodore Bent summarized in an interesting manner the results of his explorations at Zimbabwe; a paper on the orientation of which was also read by Mr. Swan. In the report of the committee appointed to assist in the exploration of Zimbabwe, it was announced that Mr. and Mrs. Bent intended to pursue their investigations into African ruins of the Zimbabwe type in Abyssinia. Mr. John Buchanan gave an account of the industrial resources of Nyasaland, which his long experience there enabled him to do with authority. The fertility of the soil, and the intelligence and willingness to work of the people, were advantages common to few parts of tropical Africa. A staple commodity was still wanting, but there were unmistakable signs that this would before long be found in coffee, which has been grown with great and increasing success. Firm government of the country, the absolute suppression of the slave-trade, and of intertribal wars, were almost certain to result from the recent extension of the British protectorate ; but the problem of communication' remained as a bar to the effective development of the country. With really free traffic on the Zambesi and lower Shire, and a railway, or at least a steam tramway, on the new road from Chilomo to Lalse Nyasa, the success of Nyasaland commercially would be assured. Lieutenant Crichton-Browne gave a popular account of a recent journey to Lobengula's capital, and of an interview with that monarch. At the close of this paper Mr. Joseph Thomson, whose health is still in a very unsatisfactory state, made a few remarks, the first he has been able to make in public since his return invalided from Africa a year ago. Dr. A. H. Hallen described the Haussa country, in the language of which he is specially interested. He hopes to be able, under the auspices of the recently-founded Haussa Association, to proceed to the western Sudan, and continue his studies in the country itself. Mr. Ravenstein submitted the report of the Committee on African meteorology, of which $\mathrm{Mr}$. Symons, F.R.S., was secretary. The Committee has collected a considerable number of unpublished records of meteorological observations in tropical Africa, and has charged itself with exercising a friendly influence over existing stations and the equipment of new stations likely to promote a better knowledge of the climatological conditions of the continent. Instructions of an eminently practical kind have been drawn up, and by the circulation of these and the grant of sets of instruments to suitable observers, it is hoped that the special difficulties of tropical observing may be overcome. The committee has been reappointed, with the addition of Dr. H. R. Mill as secretary.

Proposed New Map of the Globe.-Mr. E. G. Ravenstein explained Prof. Penck's scheme of a new map of the world, on the scale of $I$ to $I, 000,000$, or about sixteen miles to an inch. It was proposed to draw each sheet on an independent projection, the sheets embracing $5^{\circ}$ in each direction, except those for latitudes higher than $60^{\circ}$, which would have a width of $10^{\circ}$ of longitude. The map would be contoured at $100,300,500$, and I200 metres, hills would be printed in brown, and rivers in blue. The official spelling of all names written in the Roman alphabet would be adhered to, accepted names in other alphabets would be transliterated on a system to be afterwards agreed on,

NO. [ 19I, VOL. 46] 
and names in unwritten languages would be rendered phonetically. The land surface of the globe would be represented in 769 sheets, and on an edition of Iooo copies it is estimated that there would be a deficit of over $£ 100,000$ if the sheets were sold at $2 s$. This sum would require to be subscribed by the Governments interested, or by private individuals. The practicability of such a map is proved by the fact that Mr. Ravenstein has himself produced with the aid of the Royal Geographical Society 46 five-degree sheets of a map of Africa. The utility of the new map is universally conceded.

Recent Travels. - Mr. Walker Harris described an adventurous journey through Yemen in the early part of this year, during a rebellion of the Arabs against the Turks. In spite of many difficulties, including imprisonment by the Turkish authorities, Mr. Harris succeeded in reaching Sanaa from Aden, and found the country to be well watered, of magnificent fertility, and by no means badly cultivated.

Mr. Coutts Trotter summarized the recent advances in the exploration and organization of British New Guinea.

Mr. H. O. Forbes described a visit to the Chatham Islands, where he discovered the bones of a remarkable flightless bird, identical with an extinct species also found in New Zealand, which is separated by 450 miles of deep water. The inevitable inference is that a land connection must formerly have existed between the two groups of islands. The importance of a careful search for similar remains in other islands of the southern hemisphere in the light of geographical distribution and speculations as to former lands is obvious.

Mr. W. R. D. Beckett, of the British Consular service in Siam, was the first Englishman to descend the Mekong river from the Eastern Laos States to Saigon, and described the various incidents of his adventurous journey.

Mr. C. W. Campbell, of the British Consular service in China, described his journey through Northern Korea, reporting favourably on the people as compared with the Chinese in their treatment of strangers.

Other Papers:-Prof. P. H. Schoute brought forward a new scheme for draining the Zuyder Zee, and Mr. Yule Oldham, lecturer on geography at Owens College, recalled attention to the early discoveries of Cadamosto on the west of Africa in the fifteenth century.

Sub-section on Chemical Oceanography.-A joint meeting of Sections $\mathrm{B}$ and $\mathrm{E}$ was held under the presidency of $\mathrm{Mr}$. Buchanan for the consideration of a series of papers on oceanography. Mr. Buchanan communicated the result of some observations of the density of the water at a depth of 2000 fathoms off the coast of South America made by Captain Thomson, of the telegraph ship Silvertozon. They are held to demonstrate that the deep water there has come direct from the Antarctic Sea. Prof. Pettersson gave a detailed and elaborate paper on the hydrography of the Kattegat and Baltic, illustrated by numerous special maps. Observations were made simultaneously at a number of points in the Baltic and its approaches; samples of water were preserved in sealed tubes for estimation of gases, and the density was in all cases measured on shore by means of Sprengel's pyknometer. The excess of precipitation over evaporation was found to cause an outflow of comparatively fresh water and a progressive decrease in the salinity from the Skagerrak inward. The fresh Baltic stream flows close round the coast of Norway as it escapes into the Atlantic. An undercurrent of salt water inward takes place, partly by reaction and partly by the rising up of the deeper layers against the ridges which divide the Baltic area into basins. This action is not uniform, but occurs by successive impulses and pauses. The physical boundary between the North Sea and the Baltic is not in the Belts, but along the ridge joining Rigen and Felster. The great mass of Baltic water from Rügen to the Gulf of Finland is of uniform salinity ; it grows salter toward the North Sea, and freshens rapidly in the Gulf of Bothnia. In this region of uniform salinity temperature appears to be the chief cause of circulatory movement. By winter cooling a layer of intermediate minimum temperature is usually formed, in which flakes of ice may be produced that rise to the surface and consolidate there. Indications derived from observations fourteen years apart point to a partial or complete stagnation of the water in the deeper parts of the Baltic basin. The fresh Baltic stream is felt in summer far to the north along the Atlantic coast of Norway, but in winter it is greatly reduced, and comparatively warm North Sea water $\left(4^{\circ}\right.$ to $6^{\circ} \mathrm{C}$.) comes into the skagerrak. This influx is coincident with the commencement of the great herring fishery, which comes to an end when the cold Baltic outflow is re-established in spring.

Dr. Andrussoff, of St. Petersburg, summarized the results of the recent Russian investigations on the Black Sea, the most remarkable discovery being the fact that below the depth of 200 fathoms the great mass of the water is stagnant, and so highly charged with sulphuretted hydrogen that all life is impossible.

Each paper was followed by animated discussion, in which Dr. John Murray, Dr. Buchan, Prof. Hartley, Dr. J. Gibson, Mr. Irvine, and Dr. H. R. Mill took part.

\section{THE AMERICAN ASSOCIATION, PRESTDENT'S ADDRESS.'}

$A$ DIVISION of science has a work of its own to do, a work that well might be done for its own sake, and still more must be done in payment of what is due to the other divisions. Each section of our Association has its just task, and fidelity to this is an obligation to all the sections. Those engaged in any labour of science owe a debt to the world at large, and can be called to give an account of what they are doing, and what they have to do, that the truth may be shown on all sides.

If it be in my power to make the annual address of this meeting of any service at all to you who hear it-in your loyalty to the Association-I would bring before you some account of the work that is wanted in the science of chemistry. Of what the chemists have done in the past the arts of industry speak more plainly than the words of any address. Of what chemists may do in the future it would be quite in vain that I should venture to predict. But of the nature of the work that is waiting in the chemical world at the present time I desire to say what I can, and I desire to speak in the interests of science in general. The interests of science, I am well assured, cannot be held indifferent to the interests of the public at large.

It is not a small task to find out how the matter of the universe is made. The task is hard, not because of the great quantity in which matter exists, nor by reason of the multiplicity of the kinds and compounds of matter, but rather from the obscurity under which the actual composition of matter is hidden from man. The physicists reach a conclusion that matter is an array of molecules, little things, not so large as a millionth of a millimetre in size, and the formation of these they leave to the work of the chemists. The smallest objects dealt with. in science, their most distinct activities become known only by the widest exercise of inductive reason.

The realm of chemical action, the world within the molecules of matter, the abode of the chemical atoms, is indeed a new world and but little known. The speculative atoms of the ancients, mere mechanical divisions, prefiguring the molecules of modern science, yet gave no sign of the chemical atoms of this century, nor any account of what happens in a chemical change. A new field of knowledge was opened in 1774 by the discovery of oxygen, and entered upon in 1804 by the publications of Dalton, a region more remote and more difficult of access than was the unknown continent toward which Christopher Columbus set his sails three centuries earlier. The world within molecules has been open for only a hundred years. The sixteenth century was not long enough for an exploration of the continent of America, and the nineteenth has not been long enough for the undertaking of the chemists. When four centuries of search shall have been made in the world of chemical formation, then science should be ready to meet a congress of nations; to rejoice with the chemist upon the issue of his task.

It is well known that chemical labour has not been barren of returns. The products of chemical action, numbering thousands of thousands, have been sifted and measured and weighed. If you ask what happens in a common chemical change you can obtain direct answers. When coal burns in the air, how much oxygen is used up, can be stated with a degree of exactness true to the first decimal of mass, perhaps to the second, yet questionable in the third. How much carbonic acid is made can be told in weight and in volume with approaching exactness. How much heat this chemical action is worth, how much light, how much electro-motive force, what train-load of cars it can carry, how long it can make certain wheels go round,for these questions chemists and physicists are ready. With how many metals carbonic acid will unite, how many ethers it

x Address by Prof. A. B. Prescott, the retiring President, delivered at the Rochester meeting of the American Association for the Advancement of Science, August, 1892 . 